\title{
Government-University Relations: IMB or No IMB? A Comparative View of Alberta and British Columbia
}

\author{
LEE SOUTHERN* and JOHN D. DENNISON**
}

\begin{abstract}
The concept of an intermediary body $(I M B)$ between government and universities has often been debated in the literature of higher education in Canada. While much of the discussion has centred around the theoretical advantages for both organizations which would accrue from the establishment of an IMB, there have been few attempts to assess whether these advantages occur in practice.

This paper reports on the result of a study of government - university relations in Alberta and British Columbia. The major purpose was to analyse differences in matters of autonomy, budget allocation, and planning, existing between Alberta, which abolished its IMB in 1972, and British Columbia, which has had a Universities Council since 1974.

The results indicated very few differences between the two provinces in the matters under review. What did emerge, however, were some important requirements for the effective operation of universities during the financial realities of the eighties.
\end{abstract}

\section{RÉSUMÉ}

L'on a souvent discuté dans la littérature couvrant l'éducation tertiaire au Canada la question d'une agence intermédiaire entre le gouvernement et les universités. La plupart de ces discussions traitent des avantages théoriques pour les deux groupes derivant de l'établissement d'une telle agence. Il y a eu, par contre, peu d'études faites sur la façon dont ces avantages se manifestent dans la pratique.

Le présent article décrit une étude faite sur les relations entre le gouvernement et les universités en Alberta et en Colombie Britannique: il analyse les différences d'autonomie, d'allocation budgétaire, et de planning qui existent entre l'Alberta, où l'agence intermédiaire a été abolie en 1972, et la Colombie Britannique, où un Conseil des Universités existe depuis 1974.

\footnotetext{
*Universities Council of British Columbia

**The University of British Columbia
} 
Les résultats indiquent très peu de différence entre les deux provinces sur les questions couvertes par la présente enquête. Par contre, l'étude démontre qu'il existe d'importants critères nécessaires à l'opération efficace des universités pour faire face aux réalités financiaires des années quatre-vingt.

\section{INTRODUCTION}

One of the most controversial issues in the study of higher education in Canada during the past decade has been the nature of the relationship between government and universities. Since the publication of the Duff-Berdahl Report (1966) a variety of bureaucratic arrangements has developed in various provinces to facilitate matters such as the allocation of funds among institutions, program approval and the coordination of postsecondary institutions.

Most provincial jurisdictions have created an "intermediary" or "buffer" agency interposed between government and the institutions, an organizational structure used in the United Kingdom and throughout the United States. Usually, the agency is in the form of a board, council or commission with either advisory or executive powers. A recent paper by Sibley (1982) outlined in some detail the nature, role and powers of the various provincial intermediary bodies in Canada (IMBs) and also discussed many of the concomitant issues which must be addressed by these agencies in the future.

A question which was not raised in the Sibley paper, however, was whether the IMB has been of value to the universities, or the government, or both. In this context, "value" is generally interpreted as applying to such issues as the preservation of institutional autonomy, effective planning or responsiveness to specific needs, financial accountability, and the furtherance of public policy.

Given the potential advantages of intermediary bodies in their buffer role between government and postsecondary institutions, the question which follows is to what extent these theoretical advantages are actually realized in practice. More specifically, in the context of Canadian higher education, how do intermediary bodies affect the nature of relations between universities and governments.

In order to explore these, and related questions, a case study was designed which focussed upon university-government relations in two provinces, Alberta and British Columbia. The reasons for selecting these two western constituencies were quite specific and require further explanation.

The two provinces are of comparable size, both in terms of population and in the structure of their postsecondary educational systems. Alberta has four public universities (Alberta, Calgary, Lethbridge and Athabasca) the last utilizing a distance education format. British Columbia supports three universities (British Columbia, Simon Fraser and Victoria), but also has a distance education institution, The Open Learning Institute, which is empowered to grant a baccalaureate degree. In both provinces, the expansion of the university systems from a single institution occurred in the same fifteen year period, 1963-1978. The relative imbalance in the size of the universities in each region is also similar. 
On the other hand, the history of the agencies interposed between government and the universities differs significantly. As the following will describe, British Columbia has had an intermediary body during approximately the period, 1974-1985, as Alberta has been without one, 1973-1985. The coincidental time frames provide a useful basis for assessing the role and effectiveness of the organizational models used in the two provinces.

A number of other conditions are also comparable. Both governments have developed community colleges, distributed throughout the province, which feature a "university transfer" component within the curriculum. The fluctuation in participation rates of 18-24 year olds in higher education over the last 20 years is comparable. Finally, aspects of accessibility to postsecondary education, such as tuition fee levels and admission policies, are similar in both provincial university systems.

In a sense, British Columbia became the "experimental" element of the study, given its experience with the Universities Council for the past eleven years. Conversely, Alberta played the role of "control", particularly in the light of the high profile assumed by the Ministry of Advanced Education, which brought government closer to the operation of the universities.

Certain limitations are inherent in the design of the study. While the two provinces selected are comparable in many respects, neither may be assumed to be representative of conditions in other provinces. Nevertheless, this study may identify hypotheses to be tested in other provinces.

\section{Alberta History}

Prior to 1966, there was only one university, Alberta, with a main campus in Edmonton and a second campus in Calgary. However, there had been considerable expansion of the postsecondary educational system from 1957 to 1966: four public colleges were founded and two private colleges were affiliated with the University.

In 1966 the University of Calgary was born and a sweeping revision of the Universities Act was conducted. The Alberta Universities Commission was established by this new legislation to take responsibility for the future development of the newly created system. In more specific terms, the Commission's function included the distribution of government grants, the supervision of program development and planning for the future. Despite the fact that the Deputy Minister of Education and the Deputy Provincial Treasurer were both ex-officio members of the Commission, it was regarded as an autonomous corporation, independent of government. The first chairman was a former Deputy Minister of Education, Dr. W.H. Swift. The Commission was to operate for seven years, during which expansion of the system included the establishment of a third university at Lethbridge and a proposal for a fourth institution.

During the 1971 election campaign the opposition Progressive Conservatives advocated the creation of a separate Department of Advanced Education to coordinate the entire postsecondary sector. This department was established in 
1972 under a Minister of Advanced Education, James Foster. In the same year, two separate reports concerned with the planning of the college and university systems recommended the total integration of the postsecondary system within the Ministry and the dissolution of the Universities and the Colleges Commissions. It was believed that such a move would lead to more efficient and effective planning, and would help to solve continuing problems associated with credit transfer and status between the universities and colleges. One report stressed that the removal of independent inter-bodies would ensure more accountable action by government.

In 1972, the Commissions dissolved and their responsibilities transferred to the Department of Advanced Education in 1973. The department was to assume responsibility in 1975 for manpower training, apprenticeships and hospital training of nurses. In 1982, however, a separate Ministry of Manpower was created and the Advanced Education portfolio reverted to its original ministerial title.

Finally, it is worth noting that, while there has been no formalized intermediary body in Alberta since 1972, there are several groups, variously referred to as Councils, Boards or Committees, which advise the Minister on specific matters. These bodies include the Council on Admissions and Transfer, the Students Finance Board, the Apprenticeship Board, and advisory committees on College affairs, Native Peoples Education, Technical/Vocational Education, University Affairs and Further Education.

\section{British Columbia History}

As in the case of Alberta, for most of British Columbia's existence there had been only one university. First admitting students in 1915, the University of British Columbia (UBC) moved to its present Point Grey site in 1925 and by 1948 had become the second largest university in the nation.

Increased public demand for higher education encouraged the newly appointed President of UBC, Dr. John B. Macdonald, to prepare voluntarily a plan in 1962 for the future development of postsecondary education in the province.

Briefly summarized, Macdonald's proposals included:

- the creation of two other independent degree-granting institutions

- a sequential establishment of several two-year regional colleges, some of which would eventually become four-year degree granting colleges

- the formation of an Academic Board, as an accrediting agency to advise the colleges on curriculum matters

- the appointment of a University Grants Commission to advise government on the allocation of funding among the universities. (Macdonald, 1962)

In 1963 a new Universities Act established the University of Victoria from an existing college and the brand new Simon Fraser University, as well as two advisory bodies: an Academic Board, to advise the Minister of Education on academic standards and development, and an Advisory Board to recommend on 
the division of grants among universities. Amendments to the Public Schools Act provided for the establishment of regional colleges. With the opening of Simon Fraser University in 1965, the province's postsecondary educational system was radically transformed from a single university and vocational schools to a sector which today includes three public universities, fifteen community colleges, and six institutes.

With regard to the nature of government-university relations, an Advisory Committee on Inter-University relations, chaired by Dr. G.N. Perry, was established by the Department of Education. Its report in 1969 recommended the replacement of the Academic and Advisory Boards with a new intermediary body (Perry, 1969).

It was not until 1974, however, following a similar recommendation made by yet another Department of Education committee on university government, chaired by Dr. Walter Young, that an intermediary body called the Universities Council was created by statute and commenced operations in October 1974 (Young, 1974).

\section{THE CONCEPT OF AN INTERMEDIARY BODY}

The theoretical arguments supporting the concept of an intermediary in higher education arise from the intensification of government-university relations caused by the latter's increasing financial dependence upon government. Simply stated, the use of public money constitutes the essence of government-university relations. This expenditure of money necessarily entails some degree of government control and scrutiny. The crucial question relates to the nature of that control. In most of the public sector the processes for government control over the appropriation and expenditure of tax money are well established. In the case of government-university relations, however, the operational nature of that control is less clearly defined.

The intermediary body is one organizational mechanism by which many governments have sought to monitor the expenditures of public money by the universities while simultaneously respecting, to the extent practicable, their autonomy in the interests of preserving academic freedom. An international educator, Lord Robbins of the United Kingdom, has succinctly described the constitutional invention of the intermediary in this context as follows:

If the state is willing to entrust the distribution of public money for this purpose and the scrutiny of the way in which it has been spent, not directly to a government department inevitably subject to political control and influence, but indirectly to a non-political expert commission or committee; and if that body, so far as is consistent with the execution of the larger aims of public policy, makes its grants in forms which impose a minimum of precise specification on the detail of expenditure, then there is created a partial insulation which should be sufficient to protect academic institutions against the cruder incursions of politics and to create an area in which freedom to maintain their own standards and initiate their own development is reasonably 
well preserved. It can create, too, an organization in which whatever positive coordination and joint planning is necessary, can take place without political coercion. (Robbins, 1980:91)

The powers of intermediaries variously include: collection of institutional data, formulation of academic master plans, approval of new programs, discontinuance of existing programs, review of institutional budgets and allocation of system operating grants.

A large body of literature examines the effects of intermediaries and focuses generally on the balances between the powers of the agency and the powers of the institutions to control and take decisions. There are no specific guidelines resulting from these studies which would enable a government to establish a "proven" intermediary. It has been observed that:

there have been no studies to indicate that elaborate coordination does or does not affect levels of state expenditure for higher education, percentage of a population attending college, cost of instruction or increased productivity of higher education. (Berdahl, 1971: 256)

In Canada, the establishment of intermediaries occurred primarily in the $1970 \mathrm{~s}$ when most provinces effected substantial changes in their legislative arrangements of government-university relations. The Hurtubise-Rowat Report described the establishment and evolving role of these provincial mechanisms thus:

the basic problem of university-provincial relations is the role of the intermediary bodies ... these bodies originally came into existence to advise the provincial governments on the financial resources to be allocated to the universities and on the division of these resources among them. The situation has changed to such an extent that it is now the responsibility of provincial governments to ensure education and comprehensive planning of their future development.... In our view, therefore, because exclusive intervention by government is undesirable, intermediary bodies are needed not only to perform the advisory and allocative functions of the existing university commissions but also to assume these newer functions of coordination and planning. (Hurtubise-Rowat, 1970:108)

This recommendation that intermediaries accept a planning function, reflects both the American conception of the role of a coordinating agency and the terms of reference of the prototype intermediary, the British U.G.C., which were amended in 1946 to include the following:

...to assist, in consultation with the universities and other bodies concerned, the preparation and execution of such plans for the development of the universities as may from time to time be required in order to ensure that they are adequate to national needs. (Owen, 1980)

\section{Methodology}

Given the rationale advanced in support of an intermediary body in higher education, the next step in the study was to translate theory into practice by developing a procedure for gathering data regarding the actual operation of an IMB. This process was designed to isolate the impact of an intermediary body by examining current practice in the two selected provinces. 
Based upon these same theoretical premises, it could be anticipated that an IMB should influence policy in the following areas

\section{- Autonomy}

Does an IMB affect the intrusion of government into the general operation of the universities? e.g., in the setting of tuition fees, tenure practices, admission requirements for students, faculty hiring policy, etc.

- Advocacy

Is the IMB perceived as an advocate for the universities and/or for government?

\section{- Access}

Does the presence of an IMB affect the access of university personnel to the Minister, with respect to influencing government policies toward the universities?

\section{- Budget}

Is the allocation of operating and capital budgets to the universities influenced by the presence of an IMB?

What influence does an IMB have upon the internal institutional allocation of budgets?

\section{- Planning}

Does an IMB affect long and short term planning policies which involve universities?

It should be noted that, in considering the preceding questions, the influence of an IMB must be measured against the effect of its most conventional alternative - a government ministry responsible for universities. Hence, in phrasing these questions in the two selected provinces, the Universities Council was the subject in British Columbia, while the Ministry of Advanced Education was the subject in Alberta.

Although a certain amount of objective data was available, a good deal of the practical evidence consisted of the perceptions and interpretations of individuals involved in the ongoing relations between government and the institutions. Hence, two kinds of data sources were used. The first was printed materials - Council and Ministry reports, legislation, budget submissions and a variety of external and internal documents, published or not. These proved to be of less value than the second source - structured interviews with the key individuals in the broad range of government-university relations. The latter included Ministry personnel (Minister, Deputy Ministers, financial officers, planners), University officers (Presidents, Academic and Financial Vice-Presidents, planners) and members of the Universities Council and staff. Approximately thirty individuals from the two provinces were interviewed in total.

\section{Summary of Data}

\section{(a) The Political Context}

In both provinces it soon became apparent that information had to be placed in a political context before it could be interpreted: 


\section{Alberta:}

Governments of recent vintage in Alberta have held overwhelming majorities, a privilege which has allowed them to act with confidence. In particular, the Lougheed administration projects a political "personality" which has a direct influence upon its structure and mode of operation. From the beginning, this government has shown great reluctance to relegate decision-making to nonelected, apolitical bodies, such as boards or commissions. Hence, the abolition of the Commissions and the creation of the Ministry of Advanced Education.

A second political characteristic of Alberta is the tendency to rotate cabinet positions. This phenomenon creates a further reluctance by ministers to commit their successors to long-term planning decisions. This latter practice, so often regarded as a priority task for intermediary bodies in higher education, is generally absent in Alberta.

\section{British Columbia:}

Two features are relevant to the political context of government-university relations with respect to the intermediary in British Columbia. First, in common with all IMBs, the Universities Council has no public base of authority. Being a creature of the legislature, it necessarily serves at the grace of the government of the day. The principal implication of this arrangement is that in political matters, the power of Council is akin to Bagehot's well known description of the role of a constitutional monarch, "to advise, to encourage and to warn."

A second characteristic of the political context in B.C. is that while the IMB was established by a New Democratic Party government it has, for the vast majority of its existence, advised a Social Credit Government and, moreover, the same Minister from 1975 to date. The implication is that the Council, whose membership is selected by the Minister, generally reflects his philosophy and goals.

This conclusion was evidenced by Council's support of Ministerial initiatives in the expansion of the medical school at UBC, the establishment of industrial "parks" at all universities, and the support of a vehicle for educational television programming and other distance learning activities.

\section{(b) Governing Structure}

\section{Alberta:}

As described earlier, the Ministry of Advanced Education (MAE), has become a substantial bureaucracy with a staff of approximately two hundred. Besides subsuming the responsibilities of the two former Commissions, it has added a number of additional tasks. To some observers in the university sector, there is a relationship between the size of the MAE and the amount of information it demands from the institutions.

With respect to the composition of the MAE, several observers noted the absence of personnel with "strong university backgrounds," a factor which raised the issue of credibility. While there is no lack of confidence expressed in the 
current staff, it was suggested that the MAE would be strengthened by the addition of individuals with experience and established reputations in the "unique context" of the university community.

\section{British Columbia:}

The Universities Council comprises eleven appointed laymen, including the chairman, who serves a maximum of two terms. Its powers are both advisory to government in certain areas, and regulatory with respect to such matters as new program approvals, and the allocation of operating grants. Generous interpretation of the University Act (1974) gives the Council a considerable potential power with respect to influencing many aspects of the universities operation.

In 1978, a separate portfolio, the Ministry of Universities, Science and Technology was created and the incumbent Minister of Education was appointed to the portfolio. An Assistant Deputy Minister for Universities was appointed together with two management level civil servants, with a current total complement numbering less than six.

The major implications of these changes are twofold. The introduction of a limited number of civil service positions has given Council a broader working relationship with the Ministry. The latter now devotes more attention to university affairs. The new appointments, however, have created the need to define the roles and relations of the respective agencies.

Under the current legislation, no employee of the universities may be appointed to Council. The lack of practising academics on Council is seen to be a weakness in the current arrangements.

\section{(c) Autonomy}

\section{Alberta:}

The Ministry has been cognizant of the need to preserve traditional university autonomy and this commitment is generally conceded by the individual institutions. However, the term "autonomy" covers a range of precision and one Ministry official noted that autonomy of institutions is directly related to the degree of independence of their operations, financial and otherwise. In Alberta this latter characteristic is exemplified in the formal departmental structures for program approval and transferability of credit among postsecondary institutions. In the more traditional aspects of university autonomy, such as internal governance and budget allocation, Alberta's universities appear to be no less autonomous than those in other jurisdictions.

\section{British Columbia:}

The preservation of university autonomy in B.C. does not differ in principle nor perceptably in degree from Alberta. Program approval rests with the IMB in B.C. and the normal safeguards respecting the use of the public's money are statutorily reserved for the universities. Indeed, the expenditure of tax dollars in the higher education field remains as probably the most autonomous field of public 
expenditure in Canada. Despite that, however, the current atmosphere of government concern for restraint expenditure has created growing pressure for greater monitoring of university expenditure, hence a possible reduction in their autonomy, which, as Sibley noted, has never been and could never be absolute.

\section{(d) Access}

\section{Alberta:}

Ease of access to the Minister of Advanced Education by university Presidents was acknowledged by all concerned. Furthermore, access is independent of MAE. While there is general agreement that the opportunity to "state the case" directly by individual universities is of value, there is less agreement that the advantages are equitable. Not surprisingly, the larger institutions wield more influence than the smaller and there was some suggestion that the presence of an IMB might temper this advantage.

\section{British Columbia:}

In principle, access to the Minister by the three presidents of the universities is through the office of the Council. Although official communication follows that path, informal contact with the Minister has not been unusual in the past. Coincidently, the present Minister is a university professor on leave of absence, a factor which increases the probability of informal contact with the Presidents.

However, as financial difficulties raise the intensity of government-university relations in British Columbia, the Minister tends increasingly to adopt the official policy of communication through the Council. This practice reinforces one of the anticipated roles of an IMB.

\section{(e) Budget}

\section{Alberta:}

Alberta's universities are made aware of individual budget information within hours of the tabling of the provincial budget. There is no delay comparable to that often found in other constituencies where IMBs allocate global budgets to individual institutions. However, the more common problems created by an absence of multi-year financial commitments by government are also present in Alberta. The annual budgets are devised through a relatively simple formula which incorporates a base grant, an increment related partly to inflation, and additional "special" grants for designated purposes, such as newly approved programs. Despite the formula, there is an element of unpredictability regarding budgets which is associated with the degree to which increments recognize both realities of costs and also the uncertain funding of new programs, even after their approval.

\section{British Columbia:}

B.C.'s universities are normally aware of their share of the annual provincial operating grant within a month of the tabling of the government's estimates in the 
Legislature. For the three year period, 1979-1982, the budgets were calculated on the basis of an allocation formula, agreed to by the universities. For the last two years the Council maintained the same allocated shares in light of a disagreement over the basis of allocation. At no time in its history has the Council used discretionary power in the allocation process without the consent of the three universities. The issue of longer range commitments to minimal levels of funding had existed in B.C. prior to the establishment of the IMB and has been advocated by both the IMB and the universities. The government of the day has not responded to arguments on this matter. Funding is strictly an annual process - with the IMB increasing the length of time of announcement of institutional allocation by no more than thirty days.

\section{(f) Programs}

\section{Alberta:}

The program approval process in Alberta can extend as long as three years. With regard to new programs and related matters, the unwillingness of the universities to surrender critical decisions to the MAE is reflected in the increased activity of the Universities Coordinating Council. This body, defined in legislation, has power to inquire into any matter which would be aided by cooperative action among the institutions. The Council's advice on program and other matters may be offered to the Minister or the individual General Faculties Councils. Although the membership of the Coordinating Council includes nine representatives from each university, (plus one from each affiliated private college), actions can be taken by executive committee.

\section{British Columbia:}

As is normal practice in Canadian universities, each university in B.C. has devised program approval procedures, primarily involving internal senates. The final approval to offer a degree, the definitions of which have been developed by the Council in consultation with the universities, resides with the IMB. Council rarely disapproves a program but rather tends to refer questionable proposals to the proposing university for reconsideration and subsequent resubmission or withdrawal. This program approval process adds approximately 8 months beyond the initial institutional approval for a program requiring funding. There is constant review of the program approval guidelines by the Program Coordinating Committee of Council which includes university representatives (Academic VicePresidents). The process is perceived as one which is non-controversial and satisfactory to the institutions.

\section{(g) Planning}

\section{Alberta:}

The issue of planning, particularly in the long term, has been discussed earlier. While debating the notion that an IMB might be expected to plan independently of 
purely political motives, one ministry official added a specific observation. He noted that, as universities are public institutions, funded largely through public funds, no planning or similar decisions can be independent of political influence. "Rational" decisions, based largely upon educational or financial criteria, cannot occur in the absence of political realities. In the planning process for universities a combination of both types of decision-making is necessary - and government must be directly involved.

\section{British Columbia:}

Until 1983, Council had taken no formal decision to mount a systematic planning exercise for the university sector in B.C. However, in that year the Council established a strategic planning project with a management committee containing representatives, inter alia, of the Council, Ministry and universities. The Minister had often expressed an interest in a plan to rationalize academic development and indicated his support for the current initiative by the Council. It is recognized by all those interviewed that educational, financial and political factors will all bear upon the planning process. The fundamental issue in the B.C. context is the movement by Council from an advisory role, albeit with institutional and Ministry consent, to a more managerial function which allocates funding in a more dirigiste manner.

\section{Conclusions and Commentary}

As Sibley suggested in his paper, evaluation of the effectiveness of an intermediary body, as opposed to direct relations between institutions and government, must, of necessity, become a largely subjective exercise. Although there are a plethora of statements, legislated enactments and commentary at varied levels of authority, which pertain to matters of governance, this study showed that a large chasm existed between the theory and the practice of universityintermediary-government relations. Hence, the perceptions of the various constituencies proved to be invaluable.

It may well be argued that, during periods of growth in postsecondary education, when government funding is relatively generous, structure would be seen to be critical to ensuring orderly growth and institutional independence. The twin demands from universities in the sixties, "money and freedom", were often not viewed as being contradictory. The Duff-Berdahl and the Bladen Reports of 1966 and 1965, respectively, were each conceived during a time of expansion.

In 1984, however, the realities of financial restraint clearly influenced institutional views of theoretical notions of objectivity, independence and rationality, as applied to governance. In Alberta, the need for universities to lobby directly and effectively with government was regarded as critical. The suggestion of a buffer body was generally perceived as a potential obstacle to access. This view was tempered only by some observers from smaller institutions who hypothesized the possibility of more equitable treatment through an IMB. Conversely, individuals from larger universities expressed concern that a Council might "homogenize" the system, which would not satisfy the needs for "special" 
consideration arising from their institutions' size and complexity.

In British Columbia the Council was subject to criticism from several fronts, again a consequence of frustrations allied to financial restraint. The universities questioned its advocacy role with government, expressed concern over leadership and criticised the equity of its allocation of the limited government grants. Government, on the other hand, questioned the effectiveness of Council's authority to "rationalize" the activity of the universities and its ability to provide adequate accountability for the expenditure of government monies.

The study revealed some of the problems involved in analyzing the role of an intermediary body in the abstract. There is little doubt that the concept has value: it does hold the potential for rationality, for planning and rationalizing the university system independently of political motivation. Unfortunately, the political context is real and ever present and it is in this context, together with the related dimensions of financial realities that any governing structure can be measured.

In both the provinces studied, political and fiscal environments had a major impact upon views of the governing structure of postsecondary education. While this observation is neither profound nor unexpected, it proved to have an overwhelming influence upon the data.

The mandates, missions and goals of the universities in Alberta and British Columbia were essentially the same. All of them sought reasonable financial security, an opportunity to "state their case", equity and consistency of treatment, freedom to set priorities and to control their own development, and sensitivity to their problems. Whether these objectives were met through a Council or a Ministry seemed to be of no real consequence.

At the same time, government officials interviewed in both provinces were concerned with the academic development of the university sector. They appeared convinced that it should be "rationalized" for the efficient use of public monies and to generate programs of perceived direct economic benefit to the province.

In general, the Universities Council was perceived as having the potential to bring stability and rational decision-making to the system by both government and university officials. Conversely, in Alberta, the Ministry of Advanced Education was seen as having the potential to succumb to political influence if dictated. The common charge that IMBs simply imposed another "layer of bureaucracy", did not surface as an important concern. In fact, the Ministry of Advanced Education seemed to provide a bureaucracy surpassing that of the Council. Delays in the program approval process were little different in Alberta and British Columbia. Similarly, delay in budget allocation was perceived as originating in government, rather than in the Ministry of Council. In both provinces, autonomy of the universities, to the extent that such autonomy may be provided, was assured to the satisfaction of the institutions.

Planning, particularly in the long term, was limited in both provinces by similar obstacles - the unwillingness of government to commit budgets beyond one year and the concern over restriction of freedom of action by the institution, which translated into scepticism with both Ministry and Council initiatives. 
In both provinces the Minister responsible was the primary centre of concern. His knowledge about, and sensitivity to, academic issues, his influence with Treasury Board and the Cabinet, his accessibility and his method of establishing policy were all vital questions. Whether the Minister communicated with universities through a Council or his department bureaucracy was again of little consequence.

The observation that nearly unanimous theoretical support existed in government and the institutions for the arguments in favor of a buffer body was important. It was evidently believed that all of the values could be attained, but other realities demand different priorities than those of structure in governance.

One other issue, common to British Columbia respondents, should be noted. It was felt strongly that the Council could work only as well as the Minister chose to let it work. Several examples were offered which demonstrated that the referring of decisions to the Council by the Minister was somewhat inconsistent. It appeared that the political or economic impact of a particular policy matter was a factor in the Minister's decision to refer. Such practices tended to erode the perception of the Council as a bulwark against politically motivated decision in higher education and hence weakened the theoretical case for an IMB.

Clearly, it was the "characteristics" of the decision makers which was of overriding concern to university respondents. Their competence, their experience, their powers of advocacy and their values were all qualities which concerned universities in their dealing with government. Further analysis is required to establish whether this conclusion is a product of the financial times, is of greater importance within the systems under study, or even is characteristic of universities in Canada.

For the reasons noted above, it proved to be impossible to isolate the question of what advantages (or disadvantages) flow from the interposition of an intermediary body from a more complex set of related issues. The study did, however, reveal many of the practical realities of university survival in Canada in 1984.

\section{REFERENCES}

Berdahl, R.O. Statewide Coordination of Higher Education. Washington, American Council on Education, 1971.

Berghofer, D. \& Vladicka, A.S. Access to Opportunity 1905-80; The Development of PostSecondary Education in Alberta, Alberta: Advanced Education and Manpower, 1980.

Bladen, V.W. Chairman. Financing Higher Education in Canada. Report of a Commission to the Association of Universities and Colleges of Canada. University of Toronto Press, 1965.

Duff, Sir James, \& Berdahl, R.O. University Government in Canada; Report of a Commission sponsored by the Canadian Association of University Teachers and the Association of Universities and Colleges of Canada: Toronto: University of Toronto Press, 1966.

Hurtubise, R. \& Rowat, D.C., Commissioners. The University, Society and Government. The Report of the Commission on the Relations between Universities and Governments. Ottawa: University of Ottawa Press, 1970.

Macdonald, J.B. Higher Education in British Columbia and a Plan for The Future: Vancouver: University of British Columbia Press, 1962. 
Owen, T.A. Is the UGC's Buffer Principle at Risk? Times Higher Education Supplement, May 9, 1980.

Perry, G.N., Chairman. Report of the Advisory Committee on Inter-University Relations: 7 March 1969.

Robbins, L.C., Baron. Higher Education Revisited. London: MacMillan, 1980.

Sibley, W.M. The Role of Intermediary Bodies in Postsecondary Education.

Address to Council of Ministers of Education, Canada Conference on Postsecondary Education Issues in Canada for the 1980s. Toronto, October 19-22, 1982.

Young, W.D., Chairman. Report of the University Government Committee, 2 May 1974. 